\title{
THE CONTRIBUTION OF PIERLUIGI PETROBELLI TO TARTINI STUDIES
}

\author{
SERGIO DURANTE \\ Università degli Studi di Padova
}

\begin{abstract}
Izvleček: Spomladi leta 2012 je v Benetkah umrl Pierluigi Petrobelli, od začetka pa do zadnjih dni svoje muzikološke kariere zavzet raziskovalec ži $i$ vljenja in glasbene zapuščine Giuseppa Tartinija. Postavil je temelj za nadaljnje raziskave. Za svoje nenavadno vseživljenjsko zanimanje za skladatelja iz Pirana je imel objektivne (raziskovalne) in subjektivne motive. Zapustil je bogat zasebni arhiv z osebnimi spomini kot tudi dokumentarnim gradivom. Na primeru Petrobellija, a tudi drugih, avtor izpostavlja najnujnejše in pomembne smernice za nadaljnje raziskave o Tartiniju in tudi širše evropske glasbe 18. stoletja.
\end{abstract}

Ključne besede: Pierluigi Petrobelli, Giuseppe Tartini, metodologija muzikoloških raziskav, glasbene izdaje.
Abstract: In the spring of 2012 Pierluigi Petrobelli, up to the last days of his musicological activity a dedicated researcher into the life and musical oeuvre of Giuseppe Tartini, died in Venice. Petrobelli laid the foundations for all further studies on this subject. He had both objective scholarly interests as well as subjective reasons for his unusually prolonged interest in the composer from Piran. Petrobelli left a rich private archive of personal recollections and documentary evidence. Through Petrobelli's example, and also by reference to other cases, the author identifies the most urgent and significant goals for future research on Tartini and, more generally, for research on European music of the eighteenth century.

Keywords: Pierluigi Petrobelli, Giuseppe Tartini, methodology of musicological research, musical editing.

On this particular occasion, a series of essays on Tartini dedicated to our late colleague, and, to many of us, also dear friend Pierluigi Petrobelli, it is hard to decide which of the two subjects should be the prime focus. I have no doubt that Pierluigi would answer: "Tartini, of course". However, I find it impossible to ignore aspects of this scholar's personality that are relevant not only for an understanding of his contribution to the field, but even more for a continuation of his work in accordance with his wishes.

We might consider in the first place the reasons for Petrobelli's interest in Tartini, which are only apparently obvious. They might seem so in view of the fact that a young man born in 1932 and growing up in Padua, fascinated by music and by the study of music, could not but be inspired by the most influential musical figure ever active in that 
city: in a sense Tartini was - if one permits the rhetorical figure - "inevitable" for him. However, there are more profound reasons for Petrobelli's attraction to the great Piranese.

The choice of Tartini becomes less obvious if we start by considering the methodology (rather than the subject) as well as the state of musicology in Italy at the time of Petrobelli's investigations. Not only was Padua in the 1950s (typically for Italy) a city hosting almost no musicological activity, but the kind of musicology that was conducted in Italy at the time ran along lines quite unlike those that Petrobelli decided to follow.

Italian musicology of the $1950 \mathrm{~s}$, as manifested in academic institutions, was strongly dependent on the philosophical school of Italian neo-idealism: in other words, it looked to Benedetto Croce. The main concerns of this school were of a philosophical or aesthetic nature and rarely or only secondarily touched on philological or historiographical aspects; even more rarely did they engage with the technical, let alone aural, substance of music. In contrast, Petrobelli invested his energies in the painstaking investigation of the historiographical (hence philological) bases of Tartinian research through a careful re-examination of the sources. It may be recalled that his relatore at the University of Rome was Luigi Ronga, a brilliant scholar in the neo-idealistic tradition, but one whom we must also credit with open-mindedness towards Petrobelli's differing approach. It was probably owing to Ronga's influence, in addition to his own natural inclination, that Pierluigi managed to link his philological investigations to problems and perspectives of broader intellectual relevance.

I have not been able to inspect Petrobelli's Tesi di laurea (examined in 1957, when he was aged 25), and ascertain the extent to which it prefigures the text of Giuseppe Tartini, le fonti biografiche, which was published eleven years later by Peters (in collaboration with the Fondazione Cini in Venice). ${ }^{1}$ At all events, the published version - which certainly required much further research and was also preceded by Petrobelli's foundational research experience at Princeton and Berkeley - displays full intellectual maturity and mastery of the sources; it is a piece of scholarship that might be considered even today a model of accuracy constantly enriched with original ideas, many of which are still worth pursuing. ${ }^{2}$ If one general criticism can be made, it is that, in my view, the title "understates" the content of the book. While it is true that the biographical sources are carefully examined and their relationships clarified, the text investigates many further aspects, ranging from Tartinian iconography to the transmission of his theoretical works: in particular, the Treatise on Ornamentation, a major achievement that, although readily available in a (Bédier-style) edition by Erwin Jacobi, ${ }^{3}$ still awaits a satisfactory critical edition.

More minor criticism may be directed towards certain sections in which punctiliousness in the interpretation of documents (including their apparent contradictions) takes precedence over the main narrative - the consequence, perhaps, of a youthful predilection for erudition rarely found in Petrobelli's later writings. But the book was unquestionably a major piece of scholarship, in which the seeds of most later writings on Tartini - by Petrobelli and others - can be found.

1 Petrobelli, Giuseppe Tartini.

2 It is perhaps significant that no mention of Luigi Ronga is made in the foreword, where the support and collaboration of many musicologists is acknowledged.

3 Tartini, Traité des agréments. 
One aspect requiring comment relates to Petrobelli's own statement on the organization of the content of the book, delivered in an eloquent passage in his preface ("Premessa"): ${ }^{4}$

The constant need to verify statements made in the writings examined [...] has forced me from time to time to shift the focus from one subject to a different one, in order to be able to proceed more securely along the main [i.e., biographical] path.

This comment, which shows his recognition of the intrinsic difficulty of reconciling scholarly writing with narrative per se, is justified only a few lines later as follows: ${ }^{5}$

I preferred to keep the text in its original form, with all its discontinuities [...] because I believed I could maintain in this way the feeling of continuous, problematic 'suspense' that the discovery of a new document (clarifying the contents of one already known), constantly aroused; in other words, I tried to preserve within my narration the same curiosity that has kept alive the interest of this author during all these years of research, and which was in the end the secret mainspring of my work.

From the above statement emerge two elements, mutually supportive, that are relevant to an understanding not only of Petrobelli's work on Tartini, but also of his musicological output in general: an attention to the narrative dimension of historiography and to its connection with the fundamental enthusiasm that provides the motivation for research. This is not the place to discuss the different shades of meaning of the term enthusiasmos from Aristotle onwards, but let me at least observe that the Latin translation of this Greek word covers, significantly, three different areas of meaning, each corresponding to one aspect of the scholar's profile: studium, ardor, alacritas. These concepts readily map on to traits of Petrobelli's character as applied to his scholarly work and, with equal force, characterize the influence he exerted on students and colleagues.

While Le fonti biografiche was in press, three articles that presaged the major work appeared in journals of varying type. ${ }^{6}$ These did not entail a repetition or recycling of materials from the book (as is so often the case) but presented three new, in-depth analyses of selected aspects. The first two addressed rather specific themes. "Tartini, Algarotti e la corte di Dresda" and "Una presenza di Tartini a Parma nel 1728", published in 1965 and 1966, respectively. The third, "Tartini, le sue idee, il suo tempo" (1967), had a wider

4 Petrobelli, Giuseppe Tartini, 7 (the citation in the main text is my translation): "La necessità di verificare costantamente le affermazioni contenute nei testi esaminati [...] ha fatto sì che si sia dovuto di volta in volta spostare il centro d'interesse da un argomento all'altro per poter proseguire con maggiore sicurezza sul filone tel tema pricipale."

5 Petrobelli, Giuseppe Tartini, 8 (the citation in the main text is my translation): "si è preferito presentare il testo nella forma in cui esso è nato, con le sue discontinuità [...] perché si è pensato di mantenere in questo modo quel senso di continua 'suspense' problematica che la scoperta di un nuovo documento, trovato per illustrarne uno già noto, faceva immediatamente sorgere; si è voluto insomma conservare nella narrazione la stessa curiosità che ha tenuto vivo l'interesse dell'autore durante tutti questi anni di lavoro, e che è stato in fondo la molla segreta del suo operare."

6 All the major Tartini studies by Petrobelli are collected in his 1992 monograph Tartini, le sue idee e il suo tempo. 
purview and - published in a journal that enjoyed a relatively large readership - sought to open up new intellectual perspectives on Tartini, banishing the simplistic image of the eccentric composer of Il trillo del diavolo. ${ }^{7}$ At the same time, this article demonstrated the fundamental unity and complementary quality of the different sides of Tartini's activity: as violinist, composer, theorist and philosopher (or, if one prefers, man of faith).

But even the apparently minor study dealing with Tartini's visit to Parma for the Feast of the Annunciation on 25 March 1728 became the occasion for a micro-history centred on the subject of sacred music and music production, and did not grant house room to the more traditional and provincial taste for vignettes glorifying local patriotism. In other words, Petrobelli's profile as a settecentista (an eighteenth-century scholar, as opposed to a music historian pure and simple) was as much to the fore here, albeit on a reduced scale, as in the larger, European context of the essay on Tartini and Algarotti. Later in his career this cultural approach proved fruitful in the field of Mozart studies, in which he achieved recognition at the highest international level as an associate of the Mozart Akademie in Salzburg.

Although this is tangential to our theme, it is worth recalling that the Parma essay brought our author close to the consideration of singers and their pivotal position in any correct understanding of eighteenth-century music culture. This represented at the time a new and very appropriate approach to the study of Italian opera (subsequent studies of Ventura Rocchetti, also connected to Tartini, and of Anton Raaff, linked to Mozart, opened up new paths in research that were followed by scholars of the next generation). A further link between Petrobelli's studies of Tartini and those of Mozartian interest was his essay "La scuola di Tartini in Germania e la sua influenza" (1968), in which (departing from an old and "lost" reference by Adolph Beyschlag made in 1908) he developed the implications of Leopold Mozart's knowledge of Tartini's so-called Treatise on Ornamentation, a text that at that time (1754) was circulating only in manuscript form and, in the main, within the restricted circle of Tartini's students. By contextualizing this evidence within a large tableau - which included the activity of Tartini's pupils in various German courts - the author once again took the reader from the small detail to the broader picture, assessing Tartini's position on the larger European stage where he belonged.

Among the major offshoots of Le fonti biografiche, attention must be drawn to two that were destined to lead to further developments: "Tartini e la musica popolare" (1971) and "Tartini e Corelli. Preliminari per l'impostazione di un problema" (printed in 1972 but completed in 1968). Concerning the first article, I will mention only the contrast between the approach to the theme by Petrobelli, historically balanced and well aware of recent developments in Ethnomusicology, and the ideological and frankly contrived one by Lev Ginsburg in his book on Tartini published in the USSR (and translated into German in Zürich in 1976). ${ }^{8}$ In the latter, Tartini's use of folk melodies is mainly interpreted as prophetic of future music in Socialist societies - a gross mystification excusable only on account of the political climate of the time.

The study of Tartini and Corelli is relevant for its specific content - illustrating a line

7 Brainard G5. See Brainard, Le sonate per violino.

8 Ginsburg, Giuseppe Tartini. 
of "evolutionary descent" (if an extreme synthesis of Petrobelli's conclusions is permissible) within the Italian culture of Sonata and Concerto, as opposed to the more passive emulation that characterized the style of composers active outside Italy (whether or not themselves Italian); however, the Corelli conference that gave rise to the study was possibly more important from another perspective, of an institutional nature. In fact, this was the very first of a series of collaborations between the recently established Società Italiana di Musicologia and a municipal administration (of Corelli's birthplace, Fusignano in the Region Emilia-Romagna). Petrobelli, an energetic organizer, was instrumental in initiating a type of co-operation that soon became very important for the Italian Musicological Society and the prospering of Italian musicology during the 1970s and 1980s, at a time when the discipline itself was simply beyond the imagination of civil servants, even when holding responsibility for cultural institutions (I refer specifically to the Assessorati alla Cultura).

Among the essays that appeared before the Le fonti biografiche, I should have mentioned first, if following strict chronological order, a study of 1962, "Per l'edizione critica di un concerto tartiniano (D. 21)", published by the Accademia Musicale Chigiana. I have left it till last in order to emphasize the importance of this juvenile but fundamental study. It represented, in fact, the first publication concerning Tartini after Petrobelli's completion of his tesi di laurea and shows how his first preoccupation was the need to provide the public (whether performers or listeners) with reliable texts based on a professional and up-to-date scrutiny of the sources. As is indeed well known, most music by Tartini published during the nineteenth century and the first half of the twentieth century was made available in editions that are for the most part unsatisfactory by modern standards. Accordingly, the article on D. 21 aimed to provide specimen guidelines for future editors. This proved to be the case, up to a certain point, with the edition of Tartini's music edited by Claudio Scimone and Edoardo Farina: never intended as a Gesamtausgabe, this enterprise ceased after the publication of a few valuable volumes (containing both concertos and sonatas), for various related reasons:

1) the problems of a philological nature connected with the editing had been considerably underestimated;

2) the structure of the series was not clearly defined (this would be difficult to establish even today, after half a century);

3) the idea of basing the edition on the autographs alone excluded works transmitted only in the form of copies and underestimated the importance of non-autograph parallel sources authorized by Tartini;

4) a dramatic gulf existed between the scope of the enterprise and the available personnel, who consisted, essentially, of the two above-mentioned musicians.

The writings already discussed, which represent the bulk of Petrobelli's commitment to Tartini, were all published between 1962 and 1974. His musicological interests extended well beyond his first subject, embracing fields such as the already mentioned Mozartian studies, studies of Italian opera and, specifically, work on Verdi, which led him to become Director of the Istituto Nazionale di Studi Verdiani. He did not neglect earlier historical periods: together with eminent colleagues, he conceived and organized the important conference of 1980 on simple polyphony in Europe. The complete list of 
his essays - of varying size and scope - runs to over a hundred items. But it is safe to say that he never forgot his commitment to his primo amore: only he now pursued it in new ways: we should remember his entries for Tartini in various encyclopaedias, such as the New Grove in both its 1980 and 2001 editions, and his organization of, and participation in, Tartini-related conferences and seminars - the one in Padua in 1992 and those in Pirano in 1992 and 2001.

I like to recall that the conference in Padua included an interesting educational experiment involving two groups of students from the University of Rome and Padua working in parallel and exchanging ideas and information that were later summarized in the proceedings. The proceedings of the Pirano conferences contain two final contributions by Petrobelli: a selective overview of studies of Tartini from 1935 (the year when Minos Dounias's catalogue of Tartini's concertos was published $)^{9}$ up to the present day and the article "Per un'edizione delle lettere di Tartini". ${ }^{10}$ I would like to pick out a sentence from the first of these articles that says much about the character and wit of our colleague; referring to his own Le fonti biografiche, he observes: "after seven years of effort and research I have 'discovered warm water' ('ho scoperto l'acqua calda'): the main source for Tartini biography was Antonio Vandini, Tartini’s best friend and side-man for fifty years."'11

At this point, another discourse should be opened, because one of the merits of Petrobelli was not only of a scholarly nature but also "political" (lato sensu): he was strongly committed to (and successful in) establishing ties between different academic milieux, not only with regard to scholarly goals but, more importantly, aimed at the improvement of relations between persons and at dialogue between different cultural environments. This type of initiative he cherished as the basis of a process of civilization that motivated his tireless activism.

The fact that he was able to instil this ethical tenet in those who came into touch with him, not through emphatic academism but with the help of down-to-earth human warmth, was witnessed by his students and friends, who often followed him on the trails he blazed, completing or improving the work he had initiated. I will not even begin to enumerate the contributions to Tartini studies deriving directly or indirectly from his example. The very fact that Slovenian and Italian scholars (and not only ones from these two nations) are now discussing the present and future state of Tartini studies owes a lot to Pierluigi.

In conclusion, I would like to turn from these celebratory accents, occasioned by the dedication of this day to Professor Petrobelli, to those of pragmaticism so dear to him. What lies ahead of us in the domain of Tartini studies? One of the projects left incomplete on his desk was an edition of the collected letters. Only a group of these, the so-called Commercio di lettere intorno ai principij dell'Armonia [...] with count Giordano Riccati, has so far been the object of a scholarly edition (by Luca Del Fra, a former student of his). ${ }^{12}$ The preliminary work that Petrobelli had carried out on the rest of the letters is now in the hands of Candida Felici, and it is hoped that it will be published some day. An orderly collection of documents would also be beneficial to future research, as previ-

9 Dounias, Die Violinkonzerte.

${ }^{10}$ Petrobelli, "Per un'edizione delle lettere."

${ }^{11}$ Petrobelli, "Gli studi e le ricerche," 14.

12 Commercio di lettere [...]; see bibliography. 
ously unknown documents turn up in archives and private collections. But certainly, the most important goal remains the complete publication of Tartini's musical compositions, a problematic enterprise made more complex than most similar ones on account of the nature of the sources.

I can only imagine this undertaking, the scholarly foundations of which have been laid by the work of a handful of scholars (among whom I would like to mention Margherita Canale), as being a multi-national one, and I hope that the meetings in Pirano, for which we must be grateful to the sponsoring Slovenian institutions, will provide the appropriate framework in the collaborative spirit of Pierluigi Petrobelli.

\section{Bibliography}

Brainard, Paul. Le sonate per violino di Giuseppe Tartini: catalogo tematico. Padova: Accademia Tartiniana; Milano: Carisch, 1975.

Commercio di lettere intorno ai Principj dell’Armonia fra il Signor Giuseppe Tartini ed il Co. Giordano Riccati. Edited by Luca Del Fra. Lucca: LIM, 2007.

Dounias, Minos. Die Violinkonzerte Giuseppe Tartinis als Ausdruck einer Künstlerpersönlichkeit und einer Kulturepoche. Wolfenbüttel, Berlin: Georg Kallmeyer Verlag, 1935

Ginsburg, Lev. Giuseppe Tartini. Translated by Albert Palm. Adliswill, Zürich: Edition Eulenburg, 1976.

Petrobelli, Pierluigi. Giuseppe Tartini. Le fonti biografiche. Wien: Universal Edition, 1968. . "Gli studi e le ricerche su Giuseppe Tartini dal 1935 a oggi." In Giuseppe Tartini e il suo tempo, edited by Metoda Kokole, 9-15. Ljubljana: ZRC SAZU, Založba ZRC, 1997.

___ _ "La scuola di Tartini in Germania e la sua influenza," Analecta musicologica 5 (1968): 1-17.

___ _. "Per un'edizione delle lettere di Giuseppe Tartini." In Tartini "Maestro delle Nazioni” e la vita culturale delle cittadine del litorale tra i secoli XVI e XVIII, edited by Metoda Kokole, 72-80. Ljubljana: ZRC SAZU, Založba ZRC, 2002.

___ " "Per l'edizione critica di un concerto tartiniano (D. 21)." Chigiana 19 (1962): 97-128.

- "Tartini, Algarotti e la corte di Dresda.” Analecta musicologica 2(1965): 72-84. "Tartini e Corelli. Preliminari per l'impostazione di un problema." Studi corelliani [1] (1968): 99-197.

____ " "Tartini, le sue idee, il suo tempo." Nuova rivista musicale italiana 1 (1967): 651-675.

___ Tartini, le sue idee e il suo tempo. Lucca: LIM, 1992. “Una presenza di Tartini a Parma nel 1728.” Aurea Parma 1 (1966): 109-124.

Tartini, Giuseppe. Traité des agréments de la musique. Edited by Erwin R. Jacobi. Celle and New York: Moeck, 1961. 


\section{PRISPEVEK PIERLUIGIJA PETROBELLIJA K ŠTUDIJAM O TARTINIJU}

\section{Povzetek}

Prispevek osvetljuje metodologijo razprav, ki jih je Pierluigi Petrobelli posvetil raziskavam življenja in del Giuseppa Tartinija, ter jih vzporeja s smernicami italijanske muzikologije $\mathrm{v}$ šestdesetih letih in pozneje. Petrobelli je svojo poklicno muzikološko pot začel prav z obsežnejšo študijo o Tartiniju, a se je pozneje posvečal tudi drugim tematikam, kot na primer Verdijevim in Mozartovim študijam, pa tudi srednjemu veku. A kljub raznim zanimanjem se je vedno znova vračal k velikemu Pirančanu ter zanj navduševal tudi mlajše kolege, od katerih so bili številni tudi njegovi učenci na raznih univerzah po svetu. Cilj mu je bil utrditi mesto Giuseppa Tartinija kot enega osrednjih osebnosti evropske glasbene kulture 18. stoletja, pri čemer je vseskozi opozarjal na veliko potrebo po objavi njegovih zbranih glasbenih del ter poglobitvi poznavanja in razumevanja njegovih teoretskih del ter njihovih filozofskih implikacij. Glavne raziskovalne smernice, ki jih je začrtal Petrobelli, se nanašajo na skladateljev življenjepis, kulturno zgodovino, izvajalsko prakso in znanstvenokritično izdajanje njegovih glasbenih del in korespondence (slednje je bil njegov zadnji in žal nedokončani večji projekt). Bil je praktično začetnik vseh smeri raziskav v zvezi s Tartinijem, ki so jih nadaljevali raziskovalci naslednje generacije in ne nazadnje je bil prav on tudi prvi pobudnik plodnega mednarodnega sodelovanja med različnimi deželami s skupnim interesom raziskav Tartinijeve dediščine. 